\title{
Model Pembangungan Pertanian Pola Interaksi dan Interdependensi Dalam Memanfaatkan Fasilitas Pelayanan Sosial Ekonomi di Kabupaten Serdang Bedagai
}

\author{
Gustami Harahap ${ }^{(1)}$, Fatmawaty ${ }^{(2)}$ \\ Fakultas Pertanian Universitas Medan Area Medan ${ }^{(1)(2)}$ \\ gustamiharahap05@gmail.com ${ }^{(1)}$, drafatmawaty.harahap@gmail.com ${ }^{(2)}$
}

\begin{abstract}
ABSTRAK
Masyarakat sering mengalami suatu permasalahan dalam aktivitas setiap harinya terutama masalah pelayanan, seperti masalah antrian yang cukup panjang dan segala urusan publik yang cukup panjang. Pelayanan seperti ini meresahkan masyaraka terutama urusan yang sifatnya sangat mendadak dan butuh waktu yang cepat yang tidak bisa di selesaikan secara cepat. Keterlambatan dalam pelayanan ini juga kurangnya fasilitas pelayanan yang tersedia sehingga segala urusan cukup lambat dilayani. Permasalahan ini yang terjadi bukan hanya pada masyarakat diperkotaan saja tetapi pada masyarakat pedesaan juga mengalami permasalahan yang sama, baik masalah aspek sosial ekonomi.Pola interaksi dan interdependensi ini sebagai upaya dalam rangka memanfaatkan fasilitas pelayanan sosial ekonomi yang dapat meningkatkan kesejahteraan masyarakat di pedesaan terutama pada masyarakat petani yang nantinya dapat memanfaatkan pola yang akan diterapkan pada Kabupaten Serdang Bedagai.Metode pendekatan yang digunakan dalam penelitian ini adalah dengan pendekatan Structural Equetion Model (SEM). Permasalahan utama yang diteliti dan dikaji dalam penelitian ini berkaitan dengan "Penerapan Pola interaksi dan interdependensi terhadap masyarakat pedesaan di Kabupaten Serdang Bedagai Provinsi Sumatera Utara.
\end{abstract}

Kata Kunci : Pola Interaksi, Interdependensi, Fasilitas Pelayanan

\begin{abstract}
People often experience a problem in their daily activities, especially service problems, such as long queues and long public affairs. Services like this are troubling for the community, especially matters that are very sudden in nature and require fast time that cannot be completed quickly. The delay in this service is also the lack of service facilities available so that all matters are served quite slowly. These problems that occur not only in urban communities but in rural communities also experience the same problems, both in terms of socioeconomic aspects. This pattern of interaction and interdependence is an effort to take advantage of socioeconomic service facilities that can improve the welfare of people in rural areas, especially in the community. farmers who will later be able to take advantage of the pattern that will be applied in Serdang Bedagai Regency. The approach method used in this research is the Structural Equetion Model (SEM) approach. The main problem researched and studied in this study is related to "Application of interaction and interdependence patterns to rural communities in Serdang Bedagai Regency, North Sumatra Province.
\end{abstract}

Keywords: Patterns Of Interaction, Interdependence, Service Facilities 
Harahap G, Fatmawaty : Model Pembangunan Pertanian Pola Interaksi dan Interdependensi Dalam Memanfaatkan Fasilitas Pelayanan Sosial Ekonomi Di Kabupaten Serdang Bedagai

\section{PENDAHULUAN}

\section{Latar Belakang}

Pembangunan pertanian yang tangguh dicirikan oleh adanya perpaduan yang sinergis antara keunggulan komparatif (misalnya kekayaan sumberdaya alam), keunggulan kompetitif (kekuatan IPTEK) dan keunggulan kooperatif (seperti budaya lokal yang positif, unsur spritualitas dan religusitas). Ketiga keunggulan ini merupakan satu kesatuan yang harus mendapat perhatian khusus dalam pembangunan di abad ke 21 ini (Buku I Paradigma pembangunan Pertanian, 1997) Konsep pembangunan pertanian di atas perlu dilakukan oleh seluruh stakeholders (komponen yang terkait), oleh karena di Indonesia masih banyak ditemukan masalah-masalah yang berhubungan dengan pertanian, yang belum ditata dan dikelola dengan lebih baik dengan mengikuti prinsip komparatif, kompetitif dan kooperatif. Ketiga prinsip di atas belum dilakukan petani di Indonesia secara menyeluruh, dikarenakan bahwa Indonesia masih menganut dua lisme pertanian : 1 . Pertanian yang mempunyai skala kecil dan ke 2. Pertanian yang mempunyai skala usaha besar yang proporsi sangat berbeda satu dengan lainnya. Selanjutnya di era abad ke 21 ini konsep pembangunan pertanian terus menerus berkembang dari apa yang dikatakan dengan konsep agribisnis. Model pembangunan pertanian terus menerus diperlukan dan disesuaikan dengan kebijakan pembangunan kawasan, apa lagi kawasan yang yang baru dimekarkan seperti kabupaten/kota Serdang Bedagai yang masih mencari bentuk model tentang pola pembangunan pertanian dimaksud. Dengan evaluasi atas kebutuhan yang tepat bahwa pembangunan pertanian tersebut juga harus berinteraksi dan berinterdependensi terhadap fasilitas sosial ekonomi yang disediakan sehingga diharapkan dapat membantu menselaraskan sesuai dengan kebutuhan terhadap perkembangan dan pertumbuhan dari pembangunan pertanian itu dapat terwujud dengan adanya kebijakan pemerintah atau stakeholders lainnya dalam membangun fasilitas sosial ekonomi yang menjadi faktor pelancar dari pembangunan pertanian tersebut. Faktor pelancar pembangunan pertanian (the accelerators of agriculture development) bahwa tiap-tiap faktor ini berguna tetapi tidak bersifat mutlak. Pembangunan pertanian dapat terjadi, biar pun salah satu atau lebih dari faktor- faktor itu tidak ada. Namun demikian, kebanyakan negara memerlukan pembangunan pertanian secepat mungkin dan untuk mencapai tujuan itu, masing- masing faktor pelancar ini dapat sangat membantu. Faktor pelancar dimaksud adalah : 1.pendidikan pembangunan, 2. kredit produksi, 3. kegiatan bersama oleh petani, 4. perbaikan dan perluasan tanah pertanian dan ke 5. perencanaan nasional pembangunan pertanian (A.T. Mosher, 1972). Faktor-faktor pendorong pembangunan pertanian di samping itu juga adalah menyangkut fasilitas-fasilitas sosial ekonomi yang berkembang secara dinamis sesuai dengan kemajuan dan perkembangan pembangunan pertanian yang terdapat di wilayah kecamatan dan kabupaten/kota tersebut yang saling berinteraksi satu sama lain dalam membentuk kemajuan dan percepatan pembangunan pertanian di kawasan daerah yang bersangkutan. Dengan melalui penelitian ini, maka dapat diketahui model pembangunan pertanian manakah yang memberikan percepatan pembangunan pertanian yang mempunyai interdependensi dengan pembangunan fasilitas sosial ekonomi di setiap kabupaten/kota.

\section{Perumusan Masalah}

Pembangunan pertanian sangat diperlukan, guna mengikuti arus globalisasi dimaksud, sebab melalui pembangunan pertanian akan dapat dilayani segala kebutuhan dan keperluan produsen dan konsumen akan produk pertanian yang dapat dipersiapkan ke dalam bentuk apakah pengembangan pertumbuhan produk hulu (on farm product) ataukah sesuai dengan dinamika perkembangan zaman bahwa masyarakat sangat membutuhkan aneka macam turunan produk pengolahan produk hulu menjadi produk hilir (off-farm product). Seluruh kebijakan yang dilakukan adalah sesuai dengan dinamika perkembangan preferensi 
konsumen dan produsen. Perkembangan pembangunan pertanian sejak dahulu kala disajikan dengan berbagai macam bentuk atau model, yang saling berinteraksi dan berinterdependensi dengan kebutuhan pembangunan pertanian lainnya : Misalnya pembangunan pertanian yang disebut dengan panca usahatani yang dikenal dengan 1. penggunaan benih unggul, 2. pengolahan tanah, 3. pemberantasan hama dan penyakit, 4 . penggunaan pupuk yang intensif serta 5. penggunaan saluran drainase yang baik. Pembangunan pertanian di atas berkembang menjadi suatu kebijakan yang dikenal dengan 1.intensifikasi khusus, 2. ekstensifikasi khusus, 3.rehabilitasi khusus, dan 4.diversifikasi khusus yang dikenal dengan suprainsus.

\section{Tujuan Penelitian}

Untuk mengetahui bentuk model pembangunan pertanian dari pola interaksi dan interdependensi dalam memanfaatkan fasilitas pelayanan sosial ekonomi yang ada di Kabupaten Serdang Bedagai.

\section{Manfaat Penelitian}

Hasil penelitian ini diharapkan dapat menjadi bahan informasi dalam berbagai macam bentuk atau model, yang saling berinteraksi dan berinterdependensi dengan kebutuhan pembangunan pertanian lainnya : Misalnya pembangunan pertanian yang disebut dengan panca usahatani yang dikenal dengan 1. penggunaan benih unggul, 2. pengolahan tanah, 3 . pemberantasan hama dan penyakit, 4. penggunaan pupuk yang intensif serta 5. penggunaan saluran drainase yang baik.

\section{METODE PENELITIAN}

\section{Tempat dan Waktu Penelitian}

Penelitian dilaksanakan di Kabupaten Serdang Bedagai yang terdiri dari 17 Kecamatan, maka dalam tahap ini telah dilakukan survey pendahuluan tentang keadaan wilayah yang akan di teliti menyangkut mengiventarisasi model pembangunan pertanian terhadap fasilitas pelayanan sosial ekonomi.

\section{Responden dan Sumber Data}

Untuk dapat menjamin keberhasilan pengumpulan data di dalam penelitian ini,maka responden dibatasi dan ditentukan oleh mereka yang secara langsung. Dari responden atau populasi yang telah ditentukan dan dibatasi pengambilan sampel secara purposive Sampling. Sumber data dalam penelitian ini diklasifikasikan menjadi dua sumber yaitu Data Primer merupakan sumber data yang diperoleh secara langsung dari para responden yang ditetapkan yaitu : para masyarakat yang berada di wilayah pedesaan khususnya masyarakat petani. Data Sekunder sumber data sekunder dimaksudkan adalah data yang diperoleh dari kepustakaan yang berkaitan dengan materi yang berkaitan dengan fasilitas pelayanan publik.

\section{Metode dan Instrument Pengumpulan Data}

Metode ini dilakukan dengan :

1. Observasi

Dengan melakukan untuk mendahului pengumpulan data dengan tujuan untuk mendapatkan gambaran yang tepat mengenai obyek penelitian.

1. Kuesioner

Hal ini dipergunakan untuk mendapatkan data yang berhubungan dengan pokok materi penelitian ini dan ini merupakan pedoman untuk mengungkapkan tujuan dari penelitian ini.

2. Wawancara

Dalam hal ini akan digabungkan dengan tiga model wawancara yang meliputi : Wawancaraa terstruktur, semi terstruktur dan non struktur.

3. Studi dokumen 
Hal ini dimaksudkan untuk mengetahui lebih jelas data yang telah ada yang nantinya sebagai bahan perbandingan dalam penelitian ini.

\section{Perencanaan Desain Produk}

Analisis yang dilakukan dalam penelitian adalah deskriptif kualitatif dan kuantitatif. Dipergunakan metode ini dimaksudkan untuk mendapatkan gambar yang sejelas-jelasnya secara tepat dan sesuai dengan tujuan penelitian. Dari hasil analisis tersebut data diketahui dengan diberikan dan dirancang suatu model pembangunan pertanian yang pola interaksi dan interdependensi terhadap pemanfaatan fasilitas pelayanan sosial ekonomi di Kabupaten Serdang Bedagai. Melalui penelitian dan pengembangan peneliti akan menghasilkan suatu model untuk diterapkan di dalam pembangunan pertanian pola interaksi dan interdependensi terhadap pemanfaatan fasilitas pelayanan sosial ekonomi di Kabupaten Serdang Bedagai. Berdasarkan data lapangan mengenai pelayanan publik terutama fasilitas pelayanan sosial ekonomi ini tidak bisa dibiarkan begitu saja dan perlunya suatu pemikiran yang serius untuk mengatasi permasalahan ini. Hasil akhir dari kegiatan penelitian ini adalah menghasilkan suatu model untuk diterapkan dari model pola interaksi dan interdependensi terhadap pemanfaatan fasilitas pelayanan sosial ekonomi di Kabupaten Serdang Bedagai.

\section{HASIL DAN PEMBAHASAN}

Berdasarkan struktur dan pertumbuhan sosial ekonomi daerah Kabupaten Serdang Bedagai selama periode pengamatan menunjukkan bahwa laju pertumbuhan sosial ekonomi rata-rata yang terbesar dibandingkan kabupaten seumur yaitu sebesar 6,11\%. Angka ini diikuti oleh Kabupaten Pakpak Barat sebesar 6,10\%, Humbang Hasundutan 5,67\%, Samosir 5,07\% dan terakhir Nias Selatan sebesar 4,31\%. Demikian pula halnya dengan kontribusi rata-rata yang diberikan kabupaten terhadap propinsi, menunjukkan bahwa Kabupaten Serdang Bedagai memberikan kontribusi terbesar dibandingkan dengan kabupaten yang tahun pemekarannya sama dengan Kabupaten Serdang Bedagai. Laju pertumbuhannya menunjukkan bahwa Kabupaten Serdang Bedagai sebesar 6,70\%, dimana angka ini lebih besar dari Propinsi Sumatera Utara yaitu 5,49\%.

Tabel 1. Model Summary

\begin{tabular}{|c|c|c|c|c|}
\hline Model & $\mathrm{R}$ & $\begin{array}{c}\mathrm{R} \\
\text { Square }\end{array}$ & $\begin{array}{l}\text { Adjusted } \\
\text { Square }\end{array}$ & $\begin{array}{l}\text { Std. Error of } \\
\text { the Estimate }\end{array}$ \\
\hline 1 &, $723^{\mathrm{a}}$ &, 523 &, 498 & 2,21796 \\
\hline
\end{tabular}

a. Predictors: (Constant), interdepedensi, interaksi Tabel 1 di atas menunjukkan bahwa :

1. $\mathrm{R}$ menunjukkan korelasi berganda, pola interaksi $\left(\mathrm{X}_{1}\right)$ dan interdependensi $\left(\mathrm{X}_{2}\right)$ terhadap fasilitas layanan sosial ekonomi 72,3\%. Artinya hubungannya erat, semakin besar R berarti hubungannya semakin erat.

2. $\mathrm{R}$ Square $\left(\mathrm{R}^{2}\right)$ atau kuadrat $\mathrm{R}$ menunjukkan koefisien determinasi adalah sebesar 0,523 , artinya persentase pola interaksi $\left(\mathrm{X}_{1}\right)$ dan interdependensi $\left(\mathrm{X}_{2}\right)$ terhadap pelayanan sosial ekonomi sebesar 52,3\%, sedangkan sisanya sebesar 47,7\% dipengaruhi oleh variabel lain yang tidak diteliti oleh penelitian ini, digunakan untuk satu variabel independent, sedangkan variabel independent lebih dari satu sebaiknya menggunakan Adjusted $R$ Square.

3. Adjusted $R$ Square merupakan nilai $\mathrm{R}^{2}$ yang disesuaikan sehingga gambarnya lebih mendekati mutu penjajakan model dalam populasi. Dari table diatas dapat dibaca bahwa Adjusted $R$ Square $\left(\mathrm{R}^{2}\right)$ adalah 49,8\%, sedangkan sisanya 50,2\% dijelaskan oleh faktor lain.

4. Standart error of The Estimated adalah kesalahan prediksi. Standart error of The Estimated juga bisa disebut standar deviasi. Dalam kasus ini nilainya sebesar 2,21796\%. Semakin kecil berarti model semakin baik. 
Harahap G, Fatmawaty : Model Pembangunan Pertanian Pola Interaksi dan Interdependensi Dalam Memanfaatkan Fasilitas Pelayanan Sosial Ekonomi Di Kabupaten Serdang Bedagai

Tabel 2. ANOVA

\begin{tabular}{|c|c|c|c|c|c|}
\hline Model & $\begin{array}{l}\text { Sum of } \\
\text { Square }\end{array}$ & Df & $\begin{array}{l}\text { Adjusted R } \\
\text { Square }\end{array}$ & $\begin{array}{l}\text { Std. Error } \\
\text { of the } \\
\text { Estimate }\end{array}$ & Sig. \\
\hline $\begin{array}{ll}1 & \text { Regression } \\
& \text { Residual } \\
& \text { Total }\end{array}$ & $\begin{array}{l}205,114 \\
186,935 \\
392,049\end{array}$ & $\begin{array}{l}2 \\
38 \\
40\end{array}$ & $\begin{array}{l}102,557 \\
4,919\end{array}$ & 20,848 &, $000^{\mathrm{b}}$ \\
\hline
\end{tabular}

a. Dependent variabel: fasilitas pelayanan

b. Predictors: (Constant), interdepedensi, interaksi

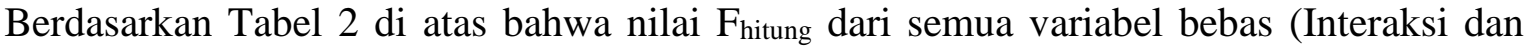
Independensi) memiliki nilai $\mathrm{F}_{\text {hitung }}$ 20,848 > Ftabel 3,245, maka $\mathrm{H}_{0}$ ditolak dan $\mathrm{H}_{\mathrm{a}}$ diterima. Berarti variabel bebas (Interaksi dan Independensi) mempunyai pengaruh dan signifikan terhadap variabel terikat (Fasilitas Pelayanan Sosial Ekonomi).

Tabel 3. Coefficients ${ }^{a}$

\begin{tabular}{|ll|l|l|l|l|l|}
\hline \multirow{2}{*}{ Model } & \multicolumn{2}{|l|}{$\begin{array}{l}\text { Unstandardized } \\
\text { Coefficients }\end{array}$} & $\begin{array}{l}\text { Standardized } \\
\text { Coefficients }\end{array}$ & $\mathrm{T}$ & Sig. \\
\cline { 3 - 7 } & $\mathrm{B}$ & Std. Error & & & \\
\hline 1 & Constant & 13,394 & 4,727 & & 2,834 &, 007 \\
& Interaksi & 2,284 &, 493 &, 566 & 4,634 &, 000 \\
& Interdependensi &, 777 &, 343 &, 277 & 2,267 &, 029 \\
\hline
\end{tabular}

a. Dependent variabel: fasilitas pelayanan

Pada Tabel 3 di atas menunjukkan bahwa perhitungan diperoleh nilai konstanta (a) 13,394, $b_{1}$ sebesar 2,284 dan $b_{2}$ sebesar 0,777, sehingga diperoleh persamaan regresi linier berganda $\mathrm{Y}=13,394+2,284 \mathrm{X}_{1}+0,777 \mathrm{X}_{2}+\mathrm{e}$, dimana interaksi dan interdepedensi mempunyai pengaruh yang signifikan terhadap variabel Fasilitas Pelayanan. Hal ini dapat dilihat dari keterangan sebagai berikut:

1. Konstanta (a) sebesar 13,394 menunjukkan bahwa tanpa adanya variabel Interaksi dan Interdepedensi besar nilai Fasilitas Pelayanan adalah sebesar 13,394.

2. Interaksi $\left(\mathrm{X}_{1}\right)$ sebesar 2,284 menunjukkan bahwa variabel Interaksi cukup berpengarh positif dan signifikan terhadap Fasilitas Pelayanan, srtinya setiap terjadi peningkatan variabel Interaksi, maka akan berpengaruh positif terhadap peningkatan Fasilitas Pelayanan.

3. Interdepedensi $\left(\mathrm{X}_{2}\right)$ sebesar 0,777 menunjukkan bahwa variabel Interdepedensi cukup berpengaruh positif dan signifikan terhadap Fasilitas Pelayanan, artinya setiap terjadi peningkatan variabel Interdepedensi, maka akan berpengaruh positif terhadap Fasilitas Pelayanan Sosial ekonomi.

\section{A. Kriteria pengambilan keputusan dengan Uji t:}

1. Ho diterima jika $t_{\text {hitung }}<t_{\text {tabel }}$ pada $\alpha=5 \%$, Tidak ada pengaruh variabel $\mathrm{X}$ terhadap variabel Y

2. Ha diterima jika $t_{\text {hitung }}>t_{\text {tabel }}$ pada $\alpha=5 \%$, Ada pengaruh variabel $X$ terhadap variabel $Y$ Analisis table diatas berdasarkan kriteria keputusan dengan Uji t mengetahui pengaruh variabel independent secara parsial terhadap variabel dependent adalah:

1) Variabel interaksi $\left(\mathrm{X}_{1}\right)$ memiliki nilai thitung $4,634>\mathrm{t}_{\text {tabel }} 2,024$, artinya berpengaruh nyata dan positif terhadap Fasilitas Pelayanan (Y)

2) Variabel Interdependensi $\left(\mathrm{X}_{2}\right)$ memiliki nilai $t_{\text {hitung }} 2,267>t_{\text {tabel }} 2,024$, artinya berpengaruh nyata dan positif terhadap Fasilitas Pelayanan (Y) 
Harahap G, Fatmawaty : Model Pembangunan Pertanian Pola Interaksi dan Interdependensi Dalam Memanfaatkan Fasilitas Pelayanan Sosial Ekonomi Di Kabupaten Serdang Bedagai

\section{B. Kriteria pengambilan keputusan dengan Signifikan:}

1. Apabila Sig. $\alpha<$ dari $\alpha=0,05$ maka variabel $X$ sangat signifikan terhadap variabel $Y$

2. Apabila Sig. $\alpha>$ dari $\alpha=0,05$ maka variabel $X$ tidak signifikan terhadap variabel $Y$

Analisis Tabel 3 di atas berdasarkan kriteria keputusan dengan Signifikan mengetahui pengaruh variabel independent secara parsial terhadap variabel dependent adalah :

1. Variabel Interaksi $\left(\mathrm{X}_{1}\right)$ memiliki nilai Sig. $\alpha=0,000<$ dari $\alpha=0,05$ artinya berpengaruh signifikan terhadap Fasilitas Pelayanan Sosial Ekonomi (Y)

2. Variabel Interdepedensi $\left(\mathrm{X}_{2}\right)$ memiliki nilai Sig. $\alpha=0,029<$ dari $\alpha=0,05$ artinya berpengaruh signifikan terhadap Fasilitas Pelayanan Sosial Ekonomi (Y)

C. Kriteria pengambilan keputusan dengan Signifikan:

Apabila Sig. $\alpha>$ dari $\alpha=0,05$ maka variabel $\mathrm{X}$ tidak signifikan terhadap variabel $\mathrm{Y}$

Tabel 4. Model Summary

\begin{tabular}{|c|c|c|l|c|}
\hline Model & $\mathrm{R}$ & $\begin{array}{c}\mathrm{R} \\
\text { Square }\end{array}$ & $\begin{array}{l}\text { Adjusted } \\
\text { Square }\end{array}$ & $\begin{array}{l}\text { Std. Error of } \\
\text { the Estimate }\end{array}$ \\
\hline 1 &, $723^{\mathrm{a}}$ &, 523 &, 498 & 2,21796 \\
\hline
\end{tabular}

a. Predictors: (Constant), interdepedensi, interaksi Tabel 4 di atas menunjukkan bahwa :

1. R menunjukkan korelasi berganda, yaitu pola interaksi $\left(X_{1}\right)$ dan interdependensi $\left(X_{2}\right)$ terhadap fasilitas layanan sosial ekonomi $72,3 \%$. Artinya hubungannya erat, semakin besar $\mathrm{R}$ berarti hubungannya semakin erat.

2. $\mathrm{R}$ Square $\left(\mathrm{R}^{2}\right)$ atau kuadrat $\mathrm{R}$ menunjukkan koefisien determinasi adalah sebesar 0,523, artinya persentase pola interaksi $\left(\mathrm{X}_{1}\right)$ dan interdependensi $\left(\mathrm{X}_{2}\right)$ terhadap pelayanan sosial ekonomi sebesar 52,3\%, sedangkan sisanya sebesar 47,7\% dipengaruhi oleh variabel lain yang tidak diteliti oleh penelitian ini. Digunakan untuk satu variabel independent, sedangkan variabel independent lebih dari satu sebaiknya menggunakan Adjusted $R$ Square.

3. Adjusted $R$ Square merupakan nilai $\mathrm{R}^{2}$ yang disesuaikan sehingga gambarnya lebih mendekati mutu penjajakan model dalam populasi. Dari table diatas dapat dibaca bahwa Adjusted $R$ Square $\left(\mathrm{R}^{2}\right)$ adalah 49,8\%, sedangkan sisanya 50,2\% dijelaskan oleh faktor lain.

4. Standart error of The Estimated adalah kesalahan prediksi. Standart error of The Estimated juga bisa disebut standar deviasi. Dalam kasus ini nilainya sebesar 2,21796\%. Semakin kecil berarti model semakin baik.

Tabel 5. ANOVA ${ }^{\mathrm{a}}$

\begin{tabular}{|ll|l|l|l|l|l|}
\hline Model & $\begin{array}{l}\text { Sum of } \\
\text { Square }\end{array}$ & Df & $\begin{array}{l}\text { Adjusted R } \\
\text { Square }\end{array}$ & $\begin{array}{l}\text { Std. Error } \\
\text { of the } \\
\text { Estimate }\end{array}$ & Sig. \\
\hline 1 & $\begin{array}{l}\text { Regression } \\
\text { Residual } \\
\text { Total }\end{array}$ & 205,114 & 2 & 102,557 & 20,848 &, $000^{\mathrm{b}}$ \\
& 186,935 & 38 & 4,919 & & \\
\hline
\end{tabular}

a. Dependent variabel: fasilitas pelayanan

b. Predictors: (Constant), interdepedensi, interaksi

Berdasarkan Tabel 5 di atas bahwa nilai $F_{\text {hitung }}$ dari semua variabel bebas (Interaksi dan Independensi) memiliki nilai $\mathrm{F}_{\text {hitung }} 20,848>$ Ftabel 3,245, maka $\mathrm{H}_{0}$ ditolak dan $\mathrm{H}_{\mathrm{a}}$ diterima. Berarti variabel bebas (Interaksi dan Independensi) mempunyai pengaruh dan signifikan terhadap variabel terikat (Fasilitas Pelayanan Sosial Ekonomi). Hasil penelitian menunjukkan kinerja ekonomi mengalami pertumbuhan yang ditandai dengan pertumbuhan 
Harahap G, Fatmawaty : Model Pembangunan Pertanian Pola Interaksi dan Interdependensi Dalam Memanfaatkan Fasilitas Pelayanan Sosial Ekonomi Di Kabupaten Serdang Bedagai

ekonomi rata-rata sebesar $6,11 \%$ dengan sektor pertanian pemberi kontribusi terbesar dengan nilai rata-rata 40,86\%, kontribusi rata-rata PDRB terhadap PDRB Propinsi sebesar $3,83 \%$. Sehingga kinerja sosial juga mengalami perubahan yang positif, yang ditandai dengan pengendalian pertumbuhan penduduk, tingkat pendidikan, kesehatan dan ketenagakerjaan yang semakin baik serta tingkat kemiskinan yang semakin menurun.

\section{KESIMPULAN}

Berdasarkan hasil penelitian dapat diambil kesimpulan bahwa model pembangunan pertanian pola interaksi dan interdepedensi dalam memanfaatkan fasilitas pelayanan sosial ekonomi di Kabupaten Serdang Bedagai yaitu :

1. Variabel pola interaksi $\left(\mathrm{X}_{1}\right)$ memiliki nilai $\mathrm{t}_{\text {hitung }} 4,634>\mathrm{t}_{\text {tabel }} 2,024$, artinya berpengaruh nyata dan positif terhadap Fasilitas Pelayanan Sosial Ekonomi (Y)

2. Variabel Interdependensi $\left(\mathrm{X}_{2}\right)$ memiliki nilai $t_{\text {hitung }} 2,267>t_{\text {tabel }} 2,024$, artinya berpengaruh nyata dan positif terhadap Fasilitas Pelayanan Sosial Ekonomi (Y)

3. Hasil penelitian bahwa nilai $F_{\text {hitung }}$ dari semua variabel bebas (Pola Interaksi dan Interdepedensi) memiliki nilai $F_{\text {hitung }} 20,484>F_{\text {tabel }}$ 3,245, maka Ho ditolak dan Ha diterima. Berarti semua variabel bebas (Pola Interaksi dan Interdepedensi) mempunyai pengaruh dan signifikan terhadap variabel terikat (Fasilitas Pelayanan Sosial Ekonomi)

\section{DAFTAR PUSTAKA}

A.T. Mosher (disadur S. Krisnandhi dan Bahren Samad), 1987 Menggerakkan dan Membangun Pertanian Syarat-Syarat Pokok Pembangunan dan Modernisasi, Penerbit CV. Yasaguna, Jakarta

Adisasmita Rahardjo, 2005 Dasar-dasar Ekonomi Wilayah, Penerbit Graha Ilmu, Jakarta Mubyarto, 1984 Pengantar Ekonomi Pertanian, Penerbit LP3ES, Jakarta

Pembangunan PertanianYang Berkebudayaan Industri, 1997 Buku I Paradigma Pembangunan Pertanian Abad21 Kerjasama Institut Pertanaian Bogor Dengan Badan Perencanaan Pembangunan Nasional

Sugeng Budiharsono, 1989 Perencanaan Pembangunan Wilayah Teori, Model Perencanaan dan Penerapannya, Penerbit Institut Pertanian Bogor (IPB), Bogor

Tati Nurmala, 2012 Pengantar Ilmu Pertanian, Penerbit Graha Ilmu, Jakarta

Tambunan Tulus, 2010 Pembangunan Pertanian dan Ketahanan Pangan, Penerbit Universitas Indonesia, Jakarta

Yuliarti, Nurheti. 2009. 1001 Cara menghasilkan Pupuk Organik. Andi Ofset. Yogyakarta.

\begin{tabular}{|l|l|l|l|}
\hline Accepted Date & Revised Date & Decided Date & Accepted to Publish \\
\hline 25 Oktober 2020 & 28 Oktober 2020 & 29 Oktober 2020 & Ya \\
\hline
\end{tabular}

